\title{
Paravortex panopea n. sp. (Platyhelminthes: Rhabdocoela) on clams from the northern Patagonian coast, Argentina: pathogeny and specificity
}

\author{
F. BRUSA ${ }^{1,2}$, N. VÁZQUEZ ${ }^{3}$, F. CREMONTE $^{3}$
}

\begin{abstract}
${ }^{1}$ División Zoología Invertebrados. Facultad de Ciencias Naturales y Museo, Universidad Nacional de La Plata, Paseo del Bosque s/n, B1900FWA, La Plata, Argentina, E-mail: fbrusa@fcnym.unlp.edu.ar; ${ }^{2}$ CONICET; ${ }^{3}$ Centro Nacional Patagónico (CONICET), Boulevard Brown 2915, U9120ACD, Puerto Madryn, Chubut, Argentina, E-mail:fcremont@cenpat.edu.ar,nuria@cenpat.edu.ar
\end{abstract}

\begin{abstract}
Summary
During a histopathological survey of the geoduck, Panopea abbreviata (Hiatellidae), and the razor clam, Ensis macha (Pharidae), in northern Patagonian gulfs (Argentina), turbellarian worms were found in the intestine lumen. In this work, we described a new species of Paravortex (Platyhelminthes, Graffillidae). We collected the hosts by scuba diving and dissected alive for studying the turbellarians. In this new species, the pharynx continues in a short esophagus and the latter in a saccular intestine. Gravid specimens have from 2 to 8 twin embryos in the parenchyma. A short penis papilla arises from the seminal vesicle and the gonopore presents a strong sphincter. This species resembled P. nicolli Szidat, 1965, which was described paraziting Mytilus edulis platensis in Buenos Aires, Argentina. The new species can be differentiated from $P$. nicolli mainly by the presence of a penis papilla and a sphincter between genital atrium and gonopore. This turbellarian species was significantly more prevalent in geoducks $(28 \%, \mathrm{n}=210)$ than in razor clams $(6 \%, \mathrm{n}=$ 480) (KW, p < 0.0001). For both host species, no evidence of direct physical damage caused by turbellarians was observed.
\end{abstract}

Keywords: Turbellaria; Graffillidae; mollusca; bivalvia; parasite; specificity

\section{Introduction}

Dalyellids "Turbellaria" (Platyhelminthes) of the genus Paravortex parasitize mainly marine bivalves, but some are associated with fishes (Lauckner, 1983; Cannon, 1986; Cannon \& Lester, 1988). This knowledge is based mostly on the work done during the late nineteenth century until the middle of the twentieth century, by researchers in the Northern Hemisphere (i.e. Europe and USA) (Brusa et al., 2006). These works were focused on bivalves of commercial interest and five species were described, while in South
America only two species from two distinct host species; one from Mytilus edulis platensis from Buenos Aires, Argentina (Szidat, 1965), and the other from Mesodesma mactroides in northern Uruguay (Brusa et al., 2006).

The aim of this work was to identify the turbellarian worms found in the intestine lumen during a health survey of the clams Panopea abbreviata and Ensis macha in northern Patagonian coast. The geoduck clam $P$. abbreviata (Valenciennes, 1839) (Hiatellidae) and the razor clam E. macha (Molina, 1782) (Pharidae) are infaunal clams inhabiting soft muddy sediments in northern Patagonia (Argentina). Both species represent a valuable fishery resource and have been exploited by artisanal fishing in the recent years (Barón et al., 2004; Morsán \& Ciocco, 2004). Moreover, we analyzed the eventual histopathological effects and the specificity of this new Paravortex species.

\section{Material and methods}

Thirty geoducks were sampled in October 2009 at Punta Conos $\left(40^{\circ} 32^{\prime} \mathrm{S}, 64^{\circ} 02^{\prime} \mathrm{W}\right)$ and 19 razor clams in November 2010 at Punta Gales $\left(42^{\circ} 25^{\prime} \mathrm{S}, 64^{\circ} 32^{\prime} \mathrm{W}\right)$ in San José Gulf. The bivalves were collected by scuba diving at approximately 15 meters depth with the help of a hidrojet to dislodge them from the sediment. Clams were maintained in an aquarium with aerated seawater at $13{ }^{\circ} \mathrm{C}$ until dissecting them under a stereomicroscope. Turbellarians were collected from the intestine, stained with neutral red and studied alive under a light microscope. Some specimens were fixed in $10 \%$ seawater formaline for histological studies (sectioned sagittally at $4 \mu \mathrm{m}$ thick, and then stained with Azan method) or for preparing in toto (stained with chlorhydric carmine and mounted in Canada balsam).

To evaluate their pathogenicity, 210 geoducks were sampled: 30 each in January, February and March of 2006 at Puerto Lobos $\left(42^{\circ} 00^{\prime} \mathrm{S}, 65^{\circ} 05^{\prime} \mathrm{W}\right)$ in San Matías Gulf $(\mathrm{n}=$ 90); and 30 seasonally during 2007 at Punta Conos 


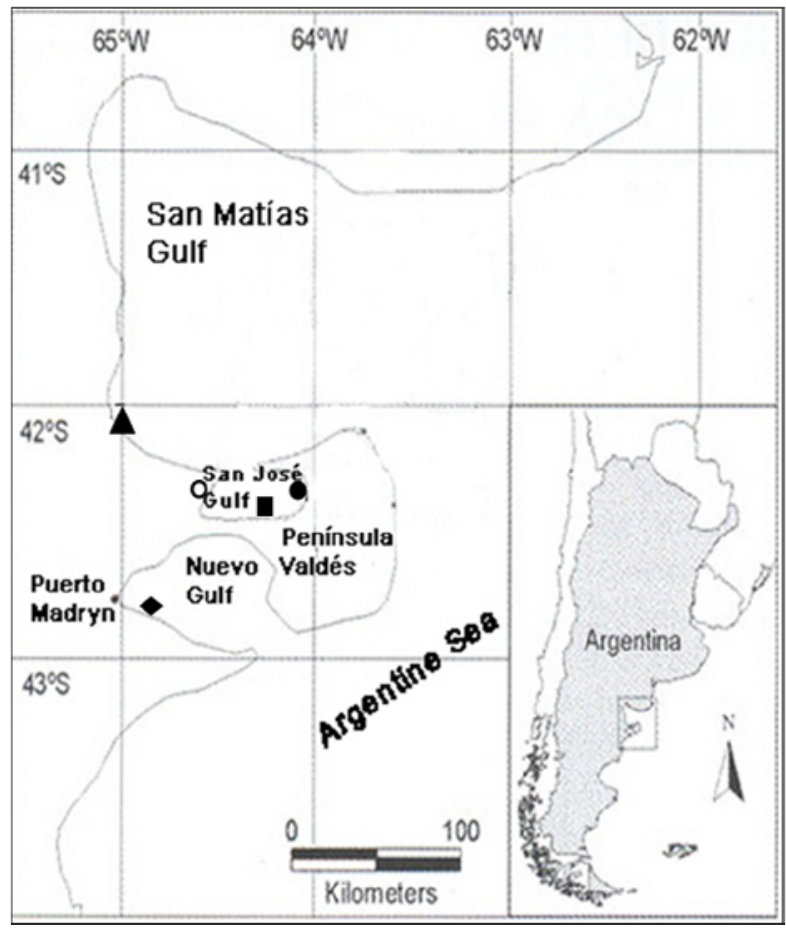

Fig. 1. Collection sites of clams Panopea abbreviata and Ensis macha in Argentine Sea.

References: $\boldsymbol{\Delta}=$ Puerto Lobos, $\mathrm{O}=\mathrm{La}$ Tapera, $\mathbf{\square}=$ Playa Fracasso, $\bullet=$ Punta Conos, $\bullet=$ Cerro Avanzado

$\left(42^{\circ} 19^{\prime} \mathrm{S}, 64^{\circ} 02^{\prime} \mathrm{W}\right)(\mathrm{n}=120)$. Also, 480 razor clams were sampled: 60 seasonally during 2007 at Puerto Lobos $(\mathrm{n}=$ 240) and at Playa Fracasso $\left(42^{\circ} 25^{\prime} \mathrm{S}, 64^{\circ} 07^{\prime} \mathrm{W}\right)$ in San José Gulf $(n=240)$ (Fig. 1). They were transported to the laboratory and maintained in aquaria with aerated seawater at $13{ }^{\circ} \mathrm{C}$ for $24 \mathrm{~h}$ until histological processing. Soft parts were fixed in Davidson's fixative (Shaw \& Battle, 1957) for $24 \mathrm{~h}$ and an oblique transverse $5 \mathrm{~mm}$ thick section (one for each geoduck and two for each razor clam) containing gills, digestive gland, mantle, nephridia and gonad was obtained, placed in a biopsy cassette, dehydrated in an ethanol series and embedded in paraffin. Histological sections (5 $\mu \mathrm{m}$ thick) were stained with Harris' hematoxylin and eosin, and observed under a light microscope.

The type material was deposited at the Helminthological Collection of Museo de La Plata, Argentina (MLP) and voucher at the Parasitological Collection of Centro Nacional Patagónico (CNP-Pa), Puerto Madryn, Argentina. Prevalence, range and mean intensities were calculated for turbellarian infection from fresh dissected clams (in this case only adults were counted) according to Bush et al. (1997), and from histological sections. Statistical analyses were conducted using non-parametric tests since the data indicated a not normal distribution. A Kruskal-Wallis (KW) test followed by post hoc $\mathrm{t}$ comparisons (Siegel \& Castellan, 1998) was performed to analyze differences in the prevalence of the two parasitized clam species from histological sections.

\section{Results}

Paravortex panopea n. sp. (Figs. 2 - 14)

Holotype: One specimen in toto, MLP

Paratypes: One specimen in toto and one specimen sagittally sectioned, MLP

Aditional material: Several specimens, CNP-Pa and MLP

Type host: Panopea abbreviata (Valenciennes, 1839) (Hiatellidae).

Other host: Ensis macha (Molina, 1782) (Pharidae).

Type locality: Punta Conos (40 $32^{\prime}$ S, 64 $64^{\circ}$ 'W) in San José Gulf, Argentina.

Other localities: Playa Fracasso $\left(42^{\circ} 25^{\prime} \mathrm{S}, 6^{\circ} 07^{\prime} \mathrm{W}\right)$ and La Tapera $\left(42^{\circ} 33^{\prime} \mathrm{S}, 6^{\circ} 55^{\prime} \mathrm{W}\right)$ in San José Gulf; Puerto Lobos $\left(42^{\circ} 00^{\prime} \mathrm{S}, 65^{\circ} 05^{\prime} \mathrm{W}\right)$ in San Matías Gulf, and Cerro Avanzado (42 $49^{\prime}$ S, $64^{\circ} 50^{\prime} \mathrm{W}$ ) in Nuevo Gulf, Argentina.

Site of infection: Intestine lumen.

Etymology: The species name refers to the generic name of the type host.

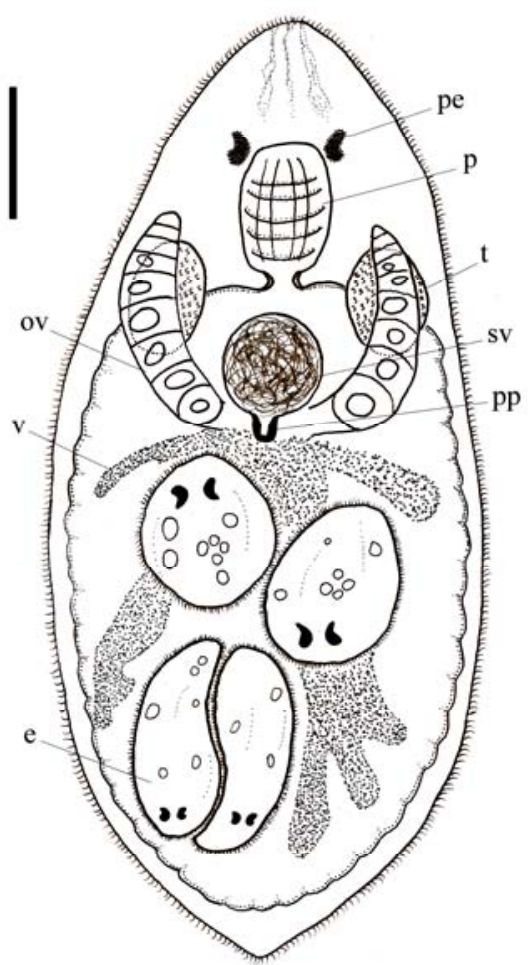

Fig. 2. Ventral view of Paravortex panopea n. sp. References: e - embryo; ov - ovary; p - pharynx; pe - pigmented eyes; pp - penis papilla; sv - seminal vesicle; $t$ - testis; $v$ - vitelline glands. Scale bar: $100 \mu \mathrm{m}$.

\section{Description}

Live specimens are white, elongated oval, and actively swimming. The body of fixed gravid specimens is oval with a rounded anterior end and a tapered rear. The size of fixed specimens is $700-1000 \mu \mathrm{m}$ long and $310-420 \mu \mathrm{m}$ maximum width $(\mathrm{n}=9)$ (Figs. 2, 3). They have a pair of 


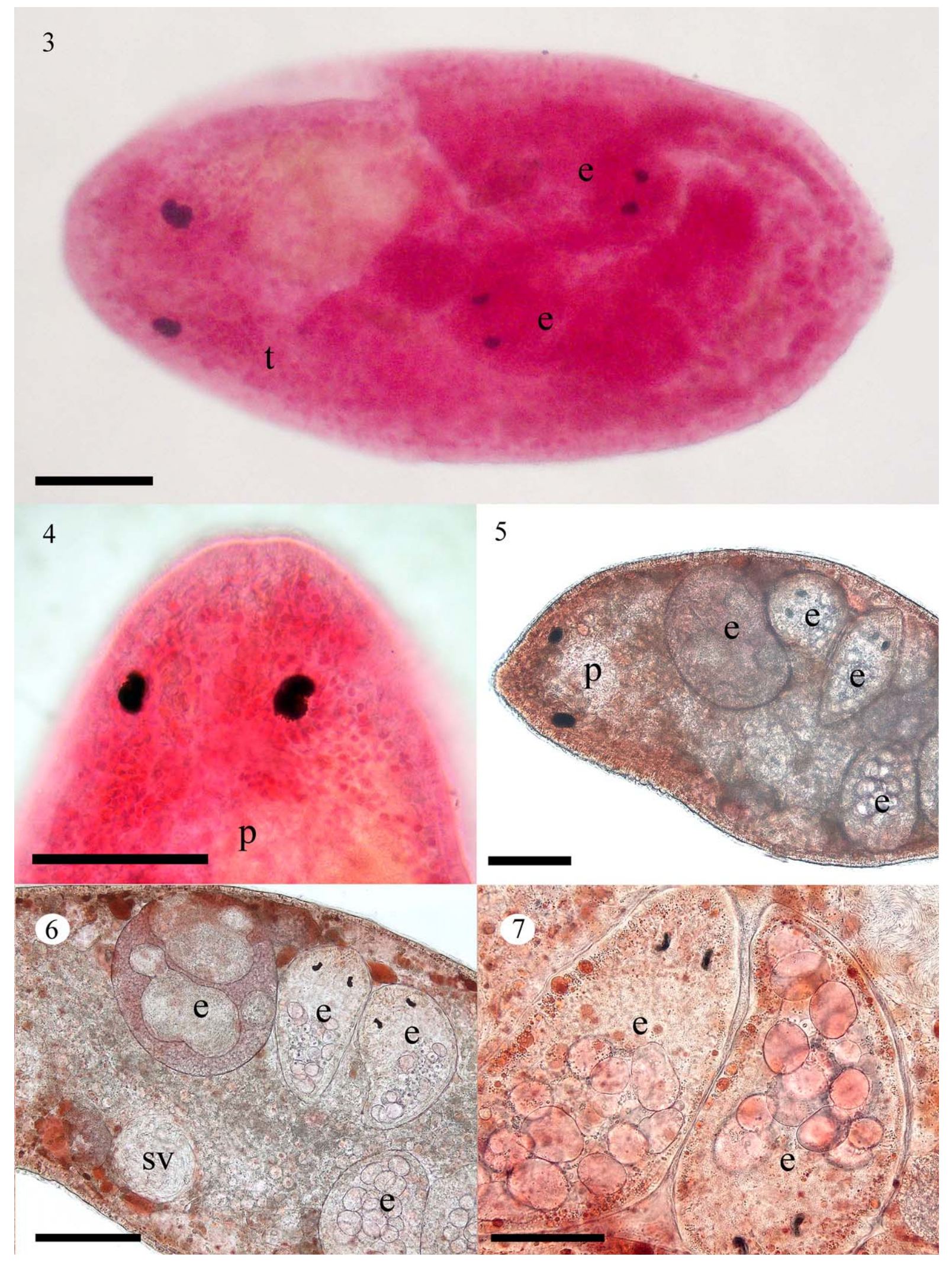

Fig. 3. - 7. Paravortex panopea n. sp. from the intestinal lumen of the geoduck clam Panopea abbreviata. 3. - 4. - In toto specimen (stained with chlorhidric carmine). 5. - 7. - Alive specimen (stained with neutral red).

References: e - embryo; p - pharynx; sv - seminal vesicle; t - testis. Scale bars 3-6: $100 \mu \mathrm{m}, 7: 50 \mu \mathrm{m}$. 

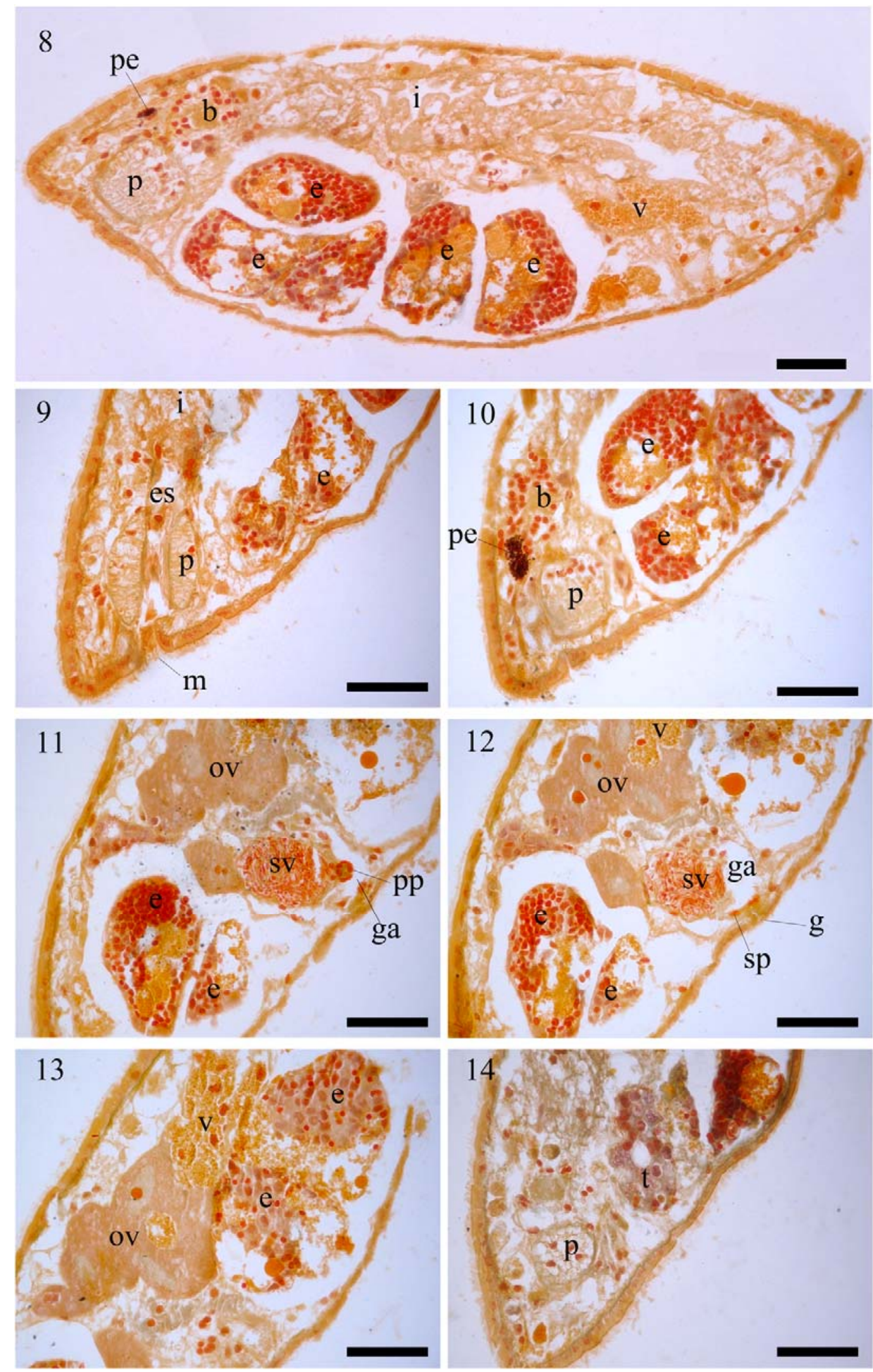

Fig. 8. - 14. Sagittaly sectioned adult specimen of Paravortex panopea n. sp. from the intestinal lumen of the geoduck clam Panopea abbreviata. References: b - brain; e - embryo; g - gonopore; ga - genital atrium; i - intestine; $m$ - mouth; es - esophagus; ov - ovary; $\mathrm{p}$ - pharynx; pe - pigmented eyes; pp - penis papilla; sp - sphincter; sv - seminal vesicle; t - testis; $\mathrm{v}$ - vitelline glands. Scale bars: $50 \mu \mathrm{m}$. 


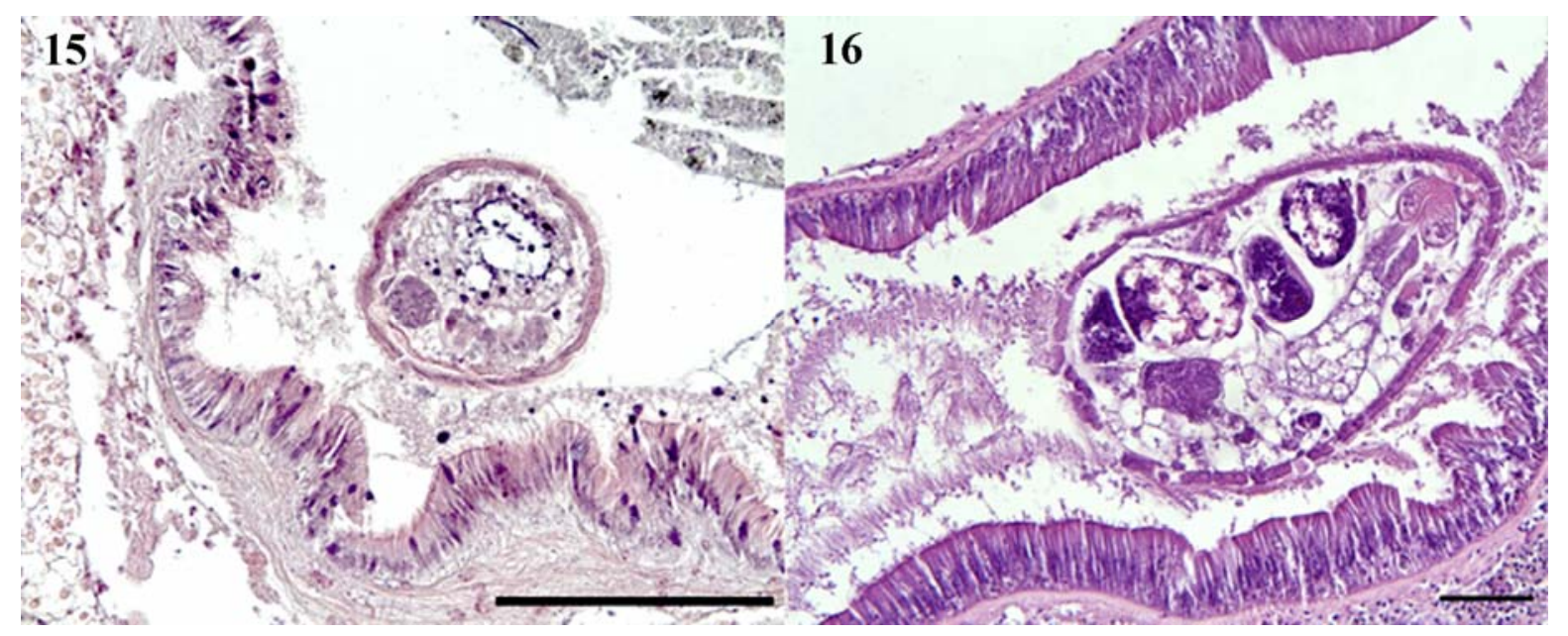

Fig. 15. - 16. Histological sections of the clams. 15. - Intestine of the geoduck Panopea abbreviata with a turbellarian worm inside. 16. - Gravid specimen of Paravortex panopea n. sp. in the intestine lumen of the razor clam Ensis macha. Scale bars: $200 \mu \mathrm{m}$.

large eyes of $25 \mu \mathrm{m}$ long with numerous corpuscles of pigment (Fig. 10), kidney-shaped with the concave part towards the periphery of the body (Fig. 4). The eyes are located slightly ahead of the pharynx (Figs. 5, 10).

The mouth is antero-dorsal and the pharynx of fixed specimens is rounded, $75-80 \mu \mathrm{m}$ in diameter $(\mathrm{n}=4)$. A short glandular esophagus opens into a large saccular intestine with a highly developed vacuolar epithelium (Figs. 8, 9).

The antero-lateral testes are located posteriorly to the pharynx, running into a pair of vas deferens leading to a seminal vesicle, always full of sperm (Figs. 2, 3, 6, 11, 12). The seminal vesicle is rounded when is observed in vivo (Fig. 6), although it may adopt an oval shape in fixed specimens (Fig. 11). The seminal vesicle communicates with the atrium through a short penial papilla (Fig. 11). The atrium opens to the outside through a middle ventral gonopore with a strong sphincter (Fig. 12).

A pair of lateral ovaries develops from the anterior region of the body towards the middle, where they attach to the vitelline glands. Vitelline glands are more developed in the posterior region of the body. The ovaries, once their join the vitelline glands, empty into the genital atrium (Figs. 12, 13). Gravid specimens have few capsules $(1-4)$ in the parenchyma, that measure $135-140 \mu \mathrm{m}$ in length $(\mathrm{n}=4)$ with twinned embryos (Figs. 2, 3, 5-8, $9-13$ ). Embryos are in pairs in a single capsule. In the same individual, embryos at different stages of development coexist, from very early stages with only one blastocyst to embryos fully developed, with eyes and cilia that allow them to move (Figs. 5 -7).

\section{Remarks}

At present, seven species of Paravortex parasitizing different species of bivalves are recognized; five of them from the Northern Hemisphere (Brusa et al. 2006). The species here described shows a greater resemblance to Paravortex nicolli Szidat, 1965, which was described parasitizing Mytilus edulis platensis (Bivalvia: Mytilidae) from Quequén, Buenos Aires, Argentina (Szidat, 1965). The validity of P. nicolli is not in doubt; however, the description is poor. The observation of the type material deposited at the Museo Argentino de Ciencias Naturales (MACN) of Buenos Aires city, Argentina, did not allow the observation of additional characters. The species here described has a similar morphology to $P$. nicolli in body size, eyes shape, pharynx, and embryo size; all these characters were seen in the specimens deposited at MACN. However, Szidat (1965) described P. nicolli as protandrous, finding no testes when embryos are present. In the case of $P$. panopea n. sp., testes were observed along with embryos (Figs. 3, 14); therefore, the development occurs simultaneously. In addition, a penis papilla and a strong sphincter between the genital atrium and gonopore are not present in $P$. nicolli. Other species of Paravortex such as P. gemellipara and P. karlingi that inhabit the North Atlantic Ocean

Table 1. Prevalence, range and mean intensity (MI) of the turbellarian Paravortex panopea $\mathrm{n}$. sp. found by different examination methods in the clams Panopea abbreviata and Ensis macha in northern Patagonian gulfs (SMG= San Matías Gulf, SJG= San José Gulf).

\begin{tabular}{ccccc}
\hline Clam species (n) & Locality & Examination method & Prevalence (\%) & Range and (MI) \\
\hline P. abbreviata (90) & Puerto Lobos (SMG) & histological section & 30.33 & $1-15(3)$ \\
P. abbreviata (120) & Punta Conos (SJG) & histological section & 23.96 & $1-14(2.65)$ \\
P. abbreviata (30) & Punta Conos (SJG) & fresh clam dissected & 66 & $1-19(3)$ \\
E. macha $(240)$ & Puerto Lobos (SMG) & histological section & 4.16 & $1(1)$ \\
E. macha $(240)$ & Fracasso Beach (SJG) & histological section & 7.08 & $1-4(1.23)$ \\
E. macha $(19)$ & Punta Gales (SJG) & fresh clam dissected & 63.16 & $3.5(1-10)$ \\
\hline
\end{tabular}


(USA, Canada and UK) also have penis papilla (Ball, 1916; Pike \& Burt, 1981). However, these last mentioned species have a larger number of capsules with twinned embryos in parenchyma (about 20 embyos vs. $2-8$ embryos) and they are smaller $(<100 \mu \mathrm{m}$ in length in $P$. gemellipara and $P$. karlingi vs. $135-140 \mu \mathrm{m}$ in length).

Table 1 shows prevalences, range and mean intensities of infection in the different populations of the clam species studied from fresh dissected clams and from histological sections. The prevalence of turbellarians was significantly higher in geoducks than in razor clams (KW; $p<0.0001)$.

From the histological sections, no damage of the intestine epithelium in either clam species was observed (Figs. $15-$ 16); however, occasionally, gravid specimens were occupying a great part of the intestine lumen.

\section{Discussion}

The new species of Paravortex is the third described from the Southern Hemisphere and the southernmost report of the genus.

The Paravortex species here described seems to exhibit some specificity for their bivalve hosts. Paravortex panopea n. sp. can be found also in E. macha with high prevalences. Whilst turbellaria have been found in low prevalences in the jingle-shell bivalve, Pododesmus rudis (4\% of 115 histological examined bivalves) and in scallops, Aequipecten tehuelchus ( $<5 \%$ of 230 histological examined scallops) in other bivalves from the same study area we have examined, turbellaria were never found [i.e., the mytilids Mytilus edulis, Aulacomya atra, Brachydontes rodriguezi the oyster Ostrea puelchana and the clam Protothaca antique, Cremonte (1999); Cremonte et al. (2005); Cremonte F. and N. Vázquez (unpublished data)] . Fresh $P$. rudis and A. tehuelchus dissected should be examined for the presence of turbellarians. We analyzed the previous records of the Paravortex species and concluded that most of them exhibit a phylogenetic host specificity, since each turbellarian species parasites one bivalve family ( $P$. cardii is found in Cardiidae, $P$. gemellipara in Mytilidae, $P$. scrobiculariae in Semelidae, and $P$. karlingi, $P$. nicolli, $P$. tapetis and $P$. mesodesma were registered in one host species). Nevertheless, it is uncertain if it is due to the specificity of the turbellarians or because other bivalves from the same area were not studied. In our case, $P$. panopea $\mathrm{n}$. sp. seems to be present in clams living in sandy substrates.

Since the graffilids lack endogenous digestive enzymes, they use their host enzymes to feed on partially digested hosts food, and their food reserves consist mainly on glycogen (as it occurs in Digenea and Cestoda); these facts represent physiological adaptations to a parasite mode of life (Jennings, 1981; Jennings \& Phillips, 1978; Jennings $\&$ Le Flore, 1979). This high degree of metabolic dependence may be responsible for the high specificity observed in the species of Paravortex.

Regarding the turbellarian pathogenicity, no evidence of direct physical damage was observed in our study, agree- ing with previous reports on bivalves infected with Paravortex (Jennings \& Phillips, 1978; Jennings \& Le Flore, 1979; Jennings, 1981). Although it seems to be innocuous to the host, some gravid specimens occupying a great part of the intestine lumen were observed, therefore they may reduce the absorption of the nutrients by obstruction.

\section{Acknowledgements}

Authors are grateful to Elizabeth Pérez Bruno for the histological examination of razor clams, Hormiga Diaz, Ricardo Vera and Fabián Quiroga for the bivalve sampling, Norma Bustos for the histological technical assistance and to Alejandro Tablado (curator of MACN, Buenos Aires, Argentina) for the loan of type specimens of $P$. nicolli. Fieldwork was conducted in a Protected Natural Area of Chubut Province with permits from the Secretaría de Turismo y Áreas Protegidas. This study was supported by ANPCyT (PICT 1374) and by UNLP travel and accommodation grant to $\mathrm{F}$ Brusa. Authors are members of CONICET.

\section{References}

BALL, S. C. (1916): The development of Paravortex gemellipara (Graffilla gemellipara Linton). J. Morphol., 27: $453-558$

BARÓn, P. J., REAL, L. E., CIOCCO, N. F., RÉ, M. E. (2004): Morphometry, growth and reproduction of an Atlantic population of the razor clam Ensis macha (Molina, 1782). Sci. Mar., 68 (2): $211-217$

Brusa, F., Ponce de León, R., Damborenea, C. (2006): A new Paravortex (Platyhelminthes, Dalyellioida) endoparasite of Mesodesma mactroides (Bivalvia, Mesodesmatidae) from Uruguay. Parasitol. Res., 95: 566 - 571. DOI: $10.1007 / \mathrm{s} 00436-006-0193-0$

Bush, A. O., Lafferty, K. D., Lotz, J. M., Shostak, A. W. (1997): Parasitology meets ecology on its own terms: Margolis et al. revisited. J. Parasitol., 83: 575 - 583. DOI: $10.2307 / 3284227$

CAnnon, L. R. G. (1986): Turbellaria of the world. A guide to families \& genera. Queensland, Australia, Queensland Museum, $136 \mathrm{pp}$.

CAnnon, L. R. G., Lester, R. J. G. (1988): Two turbellarians parasitic in fish. Dis. Aquat. Org., 5:15 - 22. DOI: 10.3354/dao005015

CREMONTE, F. (1999): Estudio parasitológico de bivalvos que habitan ambientes marinos y mixohalinos en Argentina. PhD thesis, Argentina, La Plata: Universidad Nacional de La Plata.

Cremonte, F., Figueras, A., Burreson, E. M. (2005): A histopathological survey of some commercially exploited bivalve molluscs in northern Patagonia, Argentina. Aquaculture, 249: 23 - 33. DOI: 10.1016/j.aquaculture.2005.01.024 JENNINGS, J. B. (1981): Physiological adaptations to entosymbiosis in three species of graffillid rhabdocoels. $H y$ drobiologia, 84:147 - 153. DOI: 10.1007/BF00026173 JenNings, J. B. (1997): Nutritional and Respiratory Path- 
ways to Parasitism Exemplified in the Turbellaria. Int $J$. Parasitol., 21: 679 - 691. DOI: 10.1016/S0020-7519(97) 00010-6

Jennings, J. B., LeFlore, W. B. (1979): Occurence and possible adaptive significance of some histochemically demonstrable dehydrogenases in two entosymbiotic Rhabdocoels (Platyhelminthes: Turbellaria). Comp. Biochem. Physiol. Part B, 62B(4): 301 - 304. DOI: 10.1016/03050491(79)90092-0

Jennings, J. B., Phillips, J. I. (1978): Feeding and digestion in three entosymbiotic graffilid rhabdocoels from bivalve and gastropod molluscs. Biol. Bull., 155: $542-$ 562. DOI: $10.2307 / 1540789$

LAUCKNER, G. (1983): Diseases of Mollusca: Bivalvia. In: KINNE, O. (Ed) Diseases of marine animals. Volume 2. Hamburg, Germany: Biologische Anstalt Helgoland, pp $477-961$

RECEIVED SEPTEMBER 14, 2010
Morsán, E., CiocCO, N. F. (2004): Age and growth model for the southern geoduck, Panopea abbreviata, off Puerto Lobos (Patagonia, Argentina). Fish. Res., 69: 343-348. DOI: 10.1016/j.fishres.2004.06.012

PIKE, A. W., BuRT, M. D. B. (1981): Paravortex karlingi sp. nov. from Cerastoderma edule L., in Britain. Hydrobiologia, 84: 23 - 30. DOI: 10.1007/BF00026160

Shaw, B. L., BATTLE, H. I. (1957): The gross and microscopic anatomy of the digestive tract of the oyster Crassostrea virginica (Gmelin). Can. J. Zool., 35: 325 347. DOI: 10.1139/z57-026

Siegel, S., CASTEllan, N. J. (1998): Estadística no paramétrica: aplicada a las ciencias de la conducta. 4th Edition, Trillas, México, 437 pp.

SzIDAT, L. (1965): Los parásitos de los mitílidos y los daños por ellos causados. II. Los parásitos de Mytilus edulis platensis (Orb.) (mejillón del Plata). Com. Mus. Arg. Cien. Nat. Bernardino Rivadavia, Parasitol., 1: 1 - 16 